\title{
NOTES
}

\section{THICK-BILLED WARBLER (IDUNA AEDON) AT GAMBELL, ALASKA: FIRST RECORD FOR NORTH AMERICA}

\author{
GARY H. ROSENBERG, 8101 North Wheatfield Dr., Tucson, Arizona 85741; \\ ghrosenberg@comcast.net \\ PAUL E. LEHMAN, 11192 Portobelo Dr., San Diego, California 92124; \\ lehman.paul@verizon.net \\ AARON J. LANG, 40208 Alpenglow Circle, Homer, Alaska 99603; \\ birdingak@gmail.com \\ VICTOR AND RUBEN STOLL, 899 Miller Rd., Centerville, Tennessee 37033; \\ victorjaystollnineteen80@gmail.com
}

In the evening on 8 September 2017, in the "far boneyard" at Gambell, St. Lawrence Island, Alaska $\left(63.78^{\circ} \mathrm{N}, 171.74^{\circ} \mathrm{W}\right)$, Victor and Ruben Stoll flushed a passerine they could not immediately identify. The "boneyards" are large pits excavated by the resident Yupik Natives seeking buried ivory and artifacts, a result of several thousand years of sea-mammal hunting from this island's Northwest Cape. Working these pits turns the soil, which has resulted in the growth of relatively lush vegetation consisting of two species of Artemisia, known locally as "wormwood." The combination of lush vegetation (reaching $0.5-1 \mathrm{~m}$ in height) and deep depressions that offer protection from the wind is attractive to migrant and vagrant landbirds in the otherwise flat, gravelly landscape. Soon thereafter, we, along with Greg Scyphers, Monte Taylor, and other birders then at Gambell, converged at the far boneyard in search of the bird. It was soon relocated and seen on the ground briefly by Lang, who suggested it was a Thick-billed Warbler (Iduna aedon), a bird he was familiar with from southeastern Asia and a species not previously recorded in Alaska or North America. Plumage features of this bird included brown upperparts, warm reddish-brown rump and tail, and pale underparts. Lang noticed that it had a very plain gray ("blank looking") face, lacking any noticeable eye-line or pale supercilium. It also appeared to be relatively large bodied, and long tailed. These features eliminated any other Old World warbler previously recorded in North America. The bird was flushed several more times that evening but proved difficult to see and photograph well.

The next day the bird was still present, and Rosenberg, Lang, and Scyphers obtained good photos. The bird remained there through 13 September. From observations in the field, and study of photos, we provide the following description of this individual. It was a relatively large warbler mainly brown above and grayish-white below (Figures 1-4). The upperparts, including the wings, were somewhat warm brown, becoming "warmer" or more rufescent on the rump and tail (Figure 1). This was most evident when the bird was flushed and flying away. The underparts appeared grayish-white, whiter on the throat, and buffier on the flanks and undertail coverts. The tail was both long (for a warbler) and distinctly graduated in shape. In flight and on the ground, the bird often spread its tail partially (Figures 3 and 4). The appearance of the head and crown varied from somewhat rounded to distinctly peaked or crested, depending on feather position (Figures 1 and 2). The bird lacked any eye-line or a pale supercilium, and had an almost "blank" gray appearance to the face, with a noticeable pale loral spot (Figures 1-4). The wings lacked any discernible wingbars. The primary extension looked short, and the spread wing appeared roundish (Figures 1, 2, and 4). The bill was heavy for a warbler, had a slightly but distinctly curved culmen, and was pale horn colored on the mandible and gray on the maxilla. The legs appeared gray (Figures 1-4). 


\section{NOTES}

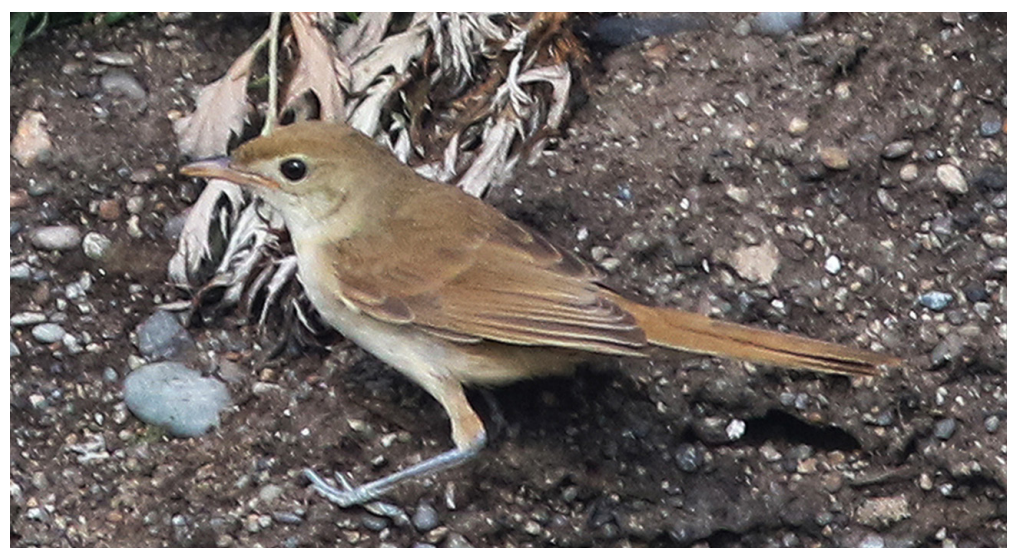

Figure 1. Thick-billed Warbler at Gambell on 9 September 2017, under neutral and flat light conditions. Many key features of this species are evident: a rather large warbler with uniform dull brown upperparts, dull grayish-white underparts, a bit browner on the flanks, a rather plain face with no eye-line or pale supercilium, a pale loral spot from the base of the bill to the eye, a rather long tail that is contrastingly more rufous (along with the rump) than the back, a relatively thick bill that has a distinct curvature to the culmen and which has a pale lower mandible. The bird lacks prominent wing-bars, although this photo shows indistinct lighter tips to both the greater and lesser wing coverts, giving the wings a slightly barred appearance, perhaps suggesting the bird was immature.

\section{Photo by Gary H. Rosenberg}

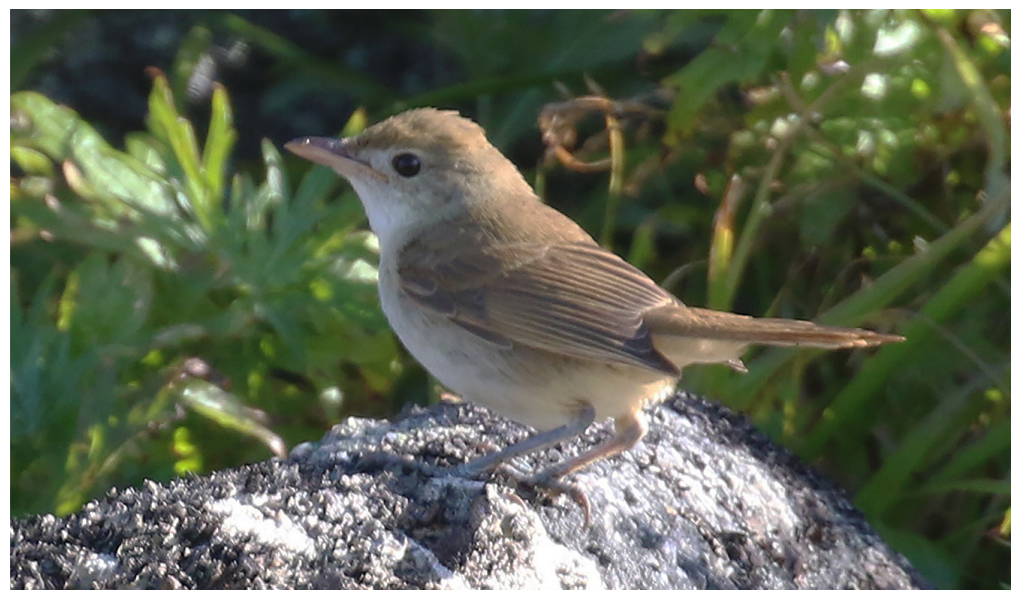

Figure 2. This photo depicts many of the same characters of the Thick-billed Warbler as shown in Figure 1. It was taken in slightly brighter light, and the browns of the wing coverts and scapulars appear somewhat warmer toned than when viewed under more neutral lighting. Also evident in this photo is the distinctly peaked crown that is characteristic of this species, as well as a "blank" face.

Photo by Greg Scyphers 


\section{NOTES}

The identification of a Thick-billed Warbler seen well is straightforward. It is the only East Asian reed warbler that lacks a distinct eye-line or supercilium. The absence of a supercilium, in combination with the bird's relatively large size, distinctly heavy bill with a curved culmen, long graduated tail, and relatively short primary projection, make it one of the more distinctive Asian reed warblers. Given that Old World vagrants documented in the Bering Sea region are not restricted to an "east Asian" origin, as attested by the Sedge Warbler (Acrocephalus schoenobaenus; Rosenberg and Lehman 2008) and others, we considered several species in the genera Iduna, Acrocephalus, and Hippolais and eliminated them as follows. The only member of this group that has previously occurred in North America is the Blyth's Reed Warbler (A. dumetorum). Four warbler species in the genus Iduna, the Booted (I. caligata), Sykes's (I. rama), Eastern Olivaceous (I. pallida), and Western Olivaceous (I. opaca), all differ from the Gambell bird in question by their smaller size, smaller bill, typically pale eye-line, distinctly less graduated and shorter tails, and in having less rufous coloration, particularly on the rump and tail. Four species of reed warbler in the genus Acrocephalus, the Blyth's, Great (A. arundinaceus), Oriental (A. orientalis), and Eurasian (A. scirpaceus), differ from the Gambell bird as follows. Blyth's has a narrow and more distinct supercilium in front of and over the eye, has a shorter and less rufescent tail that is not as graduated, and has a smaller and thinner bill. The Great Reed and Oriental Reed Warblers both have a paler supericilium, thinner and longer bill, longer primary extension, and buffier underparts and flanks that contrast with a whiter throat. The Eurasian Reed Warbler is smaller than the Thick-billed, typically shows a more distinct pale supercilium and eyering, has a shorter, less rufescent, and less graduated tail, has a smaller and thinner bill, and has a longer primary projection. The Thick-billed Warbler has a primary projection shorter than in most species of Acrocephalus. Members of the genus Hippolais can look superficially similar to Thick-billed Warbler and other species of Iduna, but they are generally grayer overall with yellowish tones, have longer and thinner bills, and often show pale edging or pale tips to the outer tail feathers.

The Thick-billed Warbler is a fairly widespread breeding bird across southeastern Asiatic Russia, Mongolia, and northeastern China, with the more westerly breeding birds constituting the nominate subspecies, aedon, and eastern birds placed in the subspecies stegmanni (Kennerley and Pearson 2010, Dyrcz 2018). The closest breeding areas are in the Amur River Basin in southeasternmost Russia, about 4300 $\mathrm{km}$ from Gambell. The Thick-billed Warbler winters in continental southeast Asia from Vietnam west through Thailand to northern and eastern India and Nepal. It is a vagrant to western Europe, with at least six records from the United Kingdom through 2017, most in the fall, as well as scattered records from Finland, Norway, and Egypt (Kennerley and Pearson 2010, BOU 2018). Gambell is at a distance similar to-but in complete mirror-image direction from-the distance between the Thickbilled Warbler's main breeding range and its winter grounds in southern Vietnam and Thailand. Misorientation and reverse migration most likely explain a majority of the vagrants that have been found at Gambell in the fall (see Howell et al. 2014 for a concise summary of this phenomenon).

The taxonomic treatment of the Thick-billed Warbler is complicated. It was long maintained in the genus Acrocephalus (Clements 2000), but for now we follow Fregin et al. (2009) and Clements et al. (2017), who place it in the genus Iduna. More recent genetic studies corroborate its differences in morphology and behavior from other members of Iduna, such as tail shape and structure, nest construction, and especially song structure (Kennerley and Pearson 2010, Arbabi et al. 2014). These support placing the Thick-billed Warbler in a monotypic genus, for which Arundinax is the oldest name, according to Pittie and Dickinson (2013).

We thank Lucas DeCicco, Daniel D. Gibson, and Kimball Garrett for making useful suggestions that improved this manuscript, as well as Greg Scyphers for contributing a photograph for this note. 


\section{NOTES}

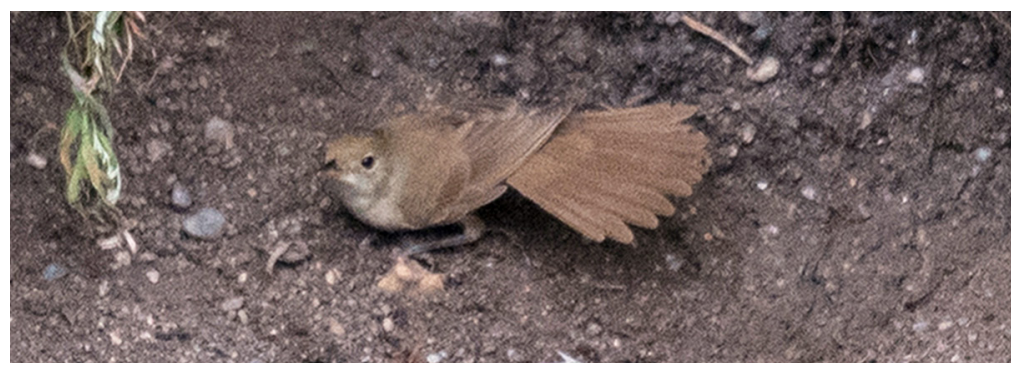

Figure 3. This photo was taken partly in neutral light, and shows the Thick-billed Warbler with the tail spread. Note the tail's length, rufescent coloration, and graduated shape.

Photo by Aaron Lang

\section{LITERATURE CITED}

Arbabi, T., Gonzalez, J., and Wink, M. 2014. A re-evaluation of phylogenetic relationships within reed warblers (Aves: Acrocephalidae) based on eight molecular loci and ISSR profiles. Mol. Phylogen. Evol. 78:304-313; doi 10.1016/j. ympev.2014.05.026.

British Ornithologists' Union (BOU). 2018. The British List: A Checklist of Birds of Britain (9th ed.). Ibis 160:190-240; doi 10.1111/ibi.12536.

Clements, J. F. 2000. Birds of the World: A Checklist. Ibis Publ., Vista, CA.

Clements, J. F., Schulenberg, T. S., Iliff, M. J., Roberson, D., Fredericks, T. A., Sullivan,

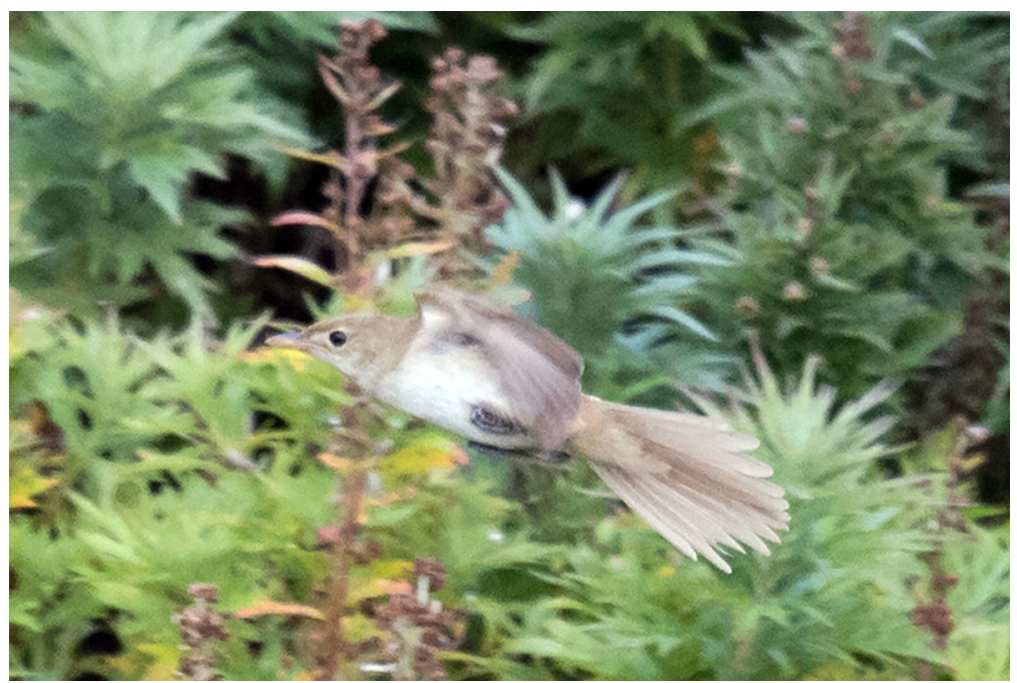

Figure 4. This photo of the Thick-billed Warbler in flight also shows the long, graduated tail, as well as the buffy brown undertail coverts. The plain face pattern, pale lores, and thick bill are also evident.

Photo by Aaron Lang 


\section{NOTES}

B. L., and Wood, C. L. 2017. The eBird/Clements checklist of birds of the world, version 2016; www.birds.cornell.edu/clementschecklist/download/.

Dyrcz, A. 2018. Thick-billed Warbler (Arundinax aedon), in Handbook of the Birds of the World Alive (J. del Hoyo, A. Elliott, J. Sargatal, D. A. Christie, and E. de Juana, eds.). Lynx Edicions, Barcelona; www.hbw.com/node/58826 (9 July 2018).

Fregin, S., Haase, M., Olsson, U., Alström, P. 2009. Multi-locus phylogeny of the family Acrocephalidae (Aves: Passeriformes) - the traditional taxonomy overthrown. Mol. Phylogen. Evol. 52:866-878; doi 10.1016/j.ympev.2009.04.006.

Howell, S. N. G., Lewington, I., and Russell, W. 2014. Rare Birds of North America. Princeton Univ. Press, Princeton, NJ; doi 10.1515/9781400848072.

Kennerley, P., and Pearson, D. 2010. Reed and Bush Warblers. Christopher Helm, London.

Pittie, A. and Dickinson, E. C. 2013. The dating of the Second Supplement to Jerdon's Catalogue of the Birds of the Peninsula of India in the Madras Journal of Literature and Science, volume 13 number 31. Zool. Bibliog. 2013 2(4):151-166.

Rosenberg, G. H., and Lehman, P. E. 2008. First North American record of Sedge Warbler (Acrocephalus schoenobaenus) at Gambell, Alaska. N. Am. Birds 62:178-181. 